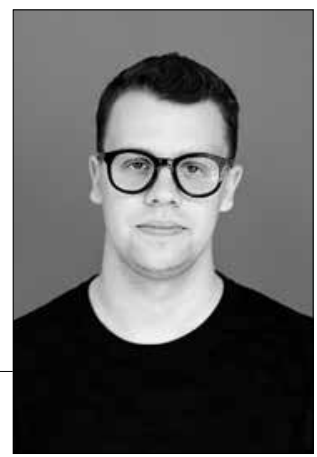

\title{
UŽDAVINIAI IR VIRŠUŽDAVINIAI VAIDYBOJE SOCIALISTINIO REALIZMO METU
}

\author{
Acting Goals and Aims under Influence of Socialist Realism
}

\author{
SUMMARY
}

The article provides new insights into the principles of the methodology of actor training developed by Konstantin Stanislavsky compared with new official wave of art in the Soviet Union - socialist realism. The article explores what was required of actors as they created roles. Why K. Stanislavskis' system was chosen as the main methodological approach is analyzed, and the features of socialist realism acting are revealed by analyzing the roles of the early Soviet era created on the stages of Lithuanian theatres.

\section{SANTRAUKA}

Straipsnyje pateikiamos naujos įžvalgos dèl Konstantino Stanislavskio plètotos aktorių rengimo metodologijos principų sąsajos su socialistinio realizmo kryptimi, egzistavusia Sovietų sąjungoje. Straipsnyje tiriama, ko buvo reikalaujama iš aktorių jiems kuriant vaidmenis; analizuojama, kodèl K. Stanislavskio sistema buvo pasirinkta kaip pagrindinè metodologinè prieiga, o socrealistinès vaidybos bruožai atskleidžiami analizuojant ankstyvojo sovietmečio vaidmenis, sukurtus Lietuvos teatrų scenose.

\section{IVADAS}

Aktorinio meistriškumo ugdymas yra neatsiejamas nuo Konstantino Stanislavskio parengtos ir praktikuotos aktoriu lavinimo sistemos, nors jų egzistuoja visa galybè, tačiau Stanislavskio metodai ìsitvirtinę labiausiai. Daugelis teatro praktikų ir teoretikų pritaria, kad ši metodologinè priemonè, skirta aktoriams parengti, yra universali. Daugiau nei šimtmeti gyvuojanti sistema nebeturètu kelti abejonių dèl savo panaudos galimybių, todèl Lietuvos teatrologijos tyrimu 
lauke Stanislavskio pedagoginių priemoniu ir jo kūrybos temos yra gana plačiai ištyrinètos. Ramunè Balevičiūtè skyrè daug dèmesio Stanislavskiui, jo sistemai ir psichologinio realizmo tyrimams, Aušra Kaminskaitè tyrinèjo psichofizini aktoriu parengimą. Lietuvoje yra daugybè autorių, kurie analizavo tiek pačią sistema, tiek Stanislavskị kaip asmenybę, tiek jo sistemos aktualumą ir universalumą. Šiuo straipsniu siekiama pateikti nauju ižvalgu apie Stanislavskio principu pritaikymą ir naujų uždavinių atsiradimą kuriant vaidmenis, kadangi Stanislavskis ir jo sistema savo pozicijas teatro pasaulyje įtvirtino Sovietų Sąungoje socialistinio realizmo i̇takos metu, režimui siekiant perkurti pasauli iš naujo, egzistuojant perkūrimo ir revizionizmo viršuždaviniui, kuris apėmė visas valstybės kontroliuojamas gyvenimo sritis. Todèl šiame straipsnyje siekiame atsakyti, kaip Sta- nislavskio sistemos principai kuriant vaidmenis buvo derinami su socialistinio realizmo ideologijos principais ir naujais uždaviniais Lietuvos teatre. Kadangi socialistinį realizmą priimtina vertinti kaip vieną iš galimų režimo naudotų kontrolès įrankių labai paranku taikyti Michelio Foucault pasiūlytą diskurso analizès metodologija. Šios metodologijos esminis principas yra atskleisti sąveiką tarp valdžios ir žinių, kurių pagalba visuomenè yra kontroliuojama per i̇vairiausias institucijas. Straipsnyje aptariamos socrealizmo atsiradimo priežastys, pokyčiai vaidybos teorijoje, kilę dèl reformų valstybejje, ir Stanislavskio indèlis į naujosios, partijos kuriamos realybès, vaidybos teoriją analizuojant laikotarpi iki praejusio amžiaus vidurio. Ryškiausi socrealistinès vaidybos ir Stanislavskio sistemos bruožai atskleidžiami naudojantis pavyzdžiais iš Lietuvos teatro scenų.

\section{NAUJA SANTVARKA - NAUJA MENO KRYPTIS}

Plètojantis SSRS vidaus politikai ir okupuojant vis daugiau teritoriju, vyko diskusijos, kokia kryptimi turètų būti formuojamas sovietinis menas, kaip ir visos kitos gyvenimo sritys, kurias vis sparčiau ėmė kontroliuoti valdžios instancijos. Sovietų Sajunga nuo pirmų savo egzistavimo minučiu èmèsi revizuoti istoriją ir kurti naujaji pasauli. Kadangi viską reikèjo perkurti, menas, kuris buvo suprantamas kaip galingas propagandos skleidèjas, susilaukè aršių diskusiju, ieškant naujos ir tinkamos jo plètros krypties (Effimova 1997: 72). Porevoliuciniu dešimtmečiu diskusijose dalyvavo dvi pagrindinès grupès: futuristai ir tradicio- nalistai (Ellis 2012: 12). Futuristai siekè atitrūkti nuo praeities atmetant viska, kas būtu siejama su ja, o tradicionalistai siekè įtvirtinti visišką realybès vaizdavimo principą mene. $1928 \mathrm{~m}$. neoficialiai pradedamas vartoti terminas - socrealizmas. Oficialūs sovietinès kultūros politikos atstovai pritarè minčiai bandyti vaizduoti realybę, tad viršu paèmè tradicionalistai. Svarbu suprasti tai, kad realybę kūrè politinis mechanizmas, o tai reiškia, kad realybè turi būti tokia, kokią ją įsivaizduoja ir nori parodyti partija (Juraga 2022: 68). Svarbia politine misija tapo nauju sovietinių idealu ir jų vaizdavimo kontrolè (Nelson 1988: 5). 
Naujai santvarkai reikejo naujos vizijos, kurią buvo privalu paversti realybe, todèl buvo pritarta, kad realizmo, kuris mègdžioja tikrovę, pagrindu galima formuoti ir ittvirtinti socrealizma, kuris taip pat mègdžios partijos utopinę tikrovę.

Oficialiai terminas pradètas vartoti tik $1932 \mathrm{~m}$. Terminas buvo patvirtintas aukščiausio rango politiku susirinkime, kuriame dalyvavo jau pirmuoju Komunistu partijos Centro komiteto sekretoriumi tapęs Josifas Stalinas (Ellis 2012: 37). Po metu Maksimas Gorkis parašo straipsni „,Socialistinis realizmas“, kuriame jis šlovina žmogų, kovojantị už so- cialini teisingumą (komunistą), bei socrealizmą vadina naujaja religija ${ }^{1}$.

Didysis lūžio taškas įvyksta 1934 m., kai rašytojų sajunga suvažiavime išskiria pagrindinius socrealizmo igyvendinimo meno kūrinyje principus ir gaires (Dubravka 2002: 68): menas turi būti artimas proletariatui, kasdienis, realus, o svarbiausia - remti partiją ir ideologiją. Sovietinès eros kultūros tyrëja Alla Efimova teigia, kad sovietmečio meno estetika siejama su didaktika, tačiau pagrindinis tikslas buvo "paveikti ir vilioti atsiduoti komunistinei realybei" (Efimova 1997: 72).

\section{KÜRYBINGUMO KONTROLE்}

Socrealizmo tikslas buvo riboti kultūrą, ją paverčiant naudinga sovietiniams idealams atskleisti. Susiformavo gana aiškios nerašytos taisyklès, kaip tapti partijai palankiu ir ištikimu kūrèju. Darbuose tapo privalu atspindèti sovietinius idealus ir aukštinti sovietu valdžia, todèl tokio tipo kūriniuose buvo juntamas optimizmas, kuris tarsi parodydavo, kaip smagiai ir linksmai gyvena liaudis, kokia yra ideali sovietinè visuomenè. Taip pat buvo svarbu aukštinti dabartí, dažnu atveju netgi niekinti praeitį. Tragedija ir negatyvūs gyvenimo vaizdiniai nebuvo leidžiami, „nebent meno kūrinyje, jie vyko kitoje vietoje ir kitu laiku" (Ellis 2012: 38), žinoma, tai buvo ankstyvuoju socialistinio realizmo vystymosi tarpsniu.

Kūrybingumas nebuvo reikšminga socrealizmo sudedamoji dalis, dažnu atveju jis net buvo atmetamas. Dažniausiai kūrejai turëjo vaizduoti sovietinius idealus, o kūriniu vertinimas tapo mechaniškas - partijos akimis, darbas arba tin- kamas, arba ne, todèl menininkui buvo svarbiausia atitikti politinę - ideologinę doktriną. Bandant paklusti oficialiems reikalavimams ir vykdant rekomendacijas, darbai dažnai tapdavo sentimentaliu "porevoliucinio romantizmo" kiču (Nelson 1988: 5). Monografijos apie kičą autorius Ludwigas Gieszas teigia, kad kičas „,siekia pagražinti gyvenimą ir paneigti blogybes, vulgaruma, kara, kaltę, vargą", o tai tiko režimui (Giesz 1994: 49).

Socialistinis realizmas įsitvirtino kaip pavyzdys, iškèlęs fizini pradą, šlovinęs sieki ginti ir didžiuotis naujaja tèvyne, skatinęs ir įrodinëjęs socialistinio gyvenimo optimizmą, tačiau ignoravęs ar net šaipęsis iš kančios ir individualaus gyvenimo, nes naujajai ideologijai individas ir psichologija bei vidinis pasaulis buvo svetimas. Čia menas ir meno kūriniai paverčiami i aiškią naudą valstybei turinčius objektus. Socrealizmas neatsiejamas ir nuo teigiamo herojaus, nes šioje meno kryptyje neigiamiems herojams vietos nebebuvo. Kūriniuose, kurie 
vaizdavo šiuolaikini žmogų tėvynẻje, neigiami personažai visuomet egzistavo užsienyje arba praeityje, nes visos neigiamybès liko istorijoje (Baliulytė 2002: 67). Kovos mene, kuris vaizduoja sovietinę realybę, vyksta tik tarp gero ir geresnio. Kaip teigia E. Baliulytè, marksizmo-leninizmo filosofijoje svarbiausia buvo idejjinis kūrinio turinys, o raiškos formos, estetinès vertès klausimas nebuvo keliamas reglamentuotai, tai ele- mentariai buvo apibrèžiama liaudiškumo sąvoka (Baliulytė 2002: 72). Bet kokios kitos modernistinès ar eksperimentinès krypties ir formos akivaizdus palaikymas ar propagavimas galèjo būti palydètas epitetais: formalizmas, modernizmas. Mat ideologijos požiūriu tokie vertinimai implikavo, kad žmonių dèmesys atitraukiamas nuo komunistinio gyvenimo tikslų ir šitaip teršiamas ju protas (Baliulytė 2002: 95).

\section{STANISLAVSKIO SISTEMA IR NAUJI UŽDAVINIAI}

O Stanislavskis liko nuošaliau nuo Spalio revoliucijos atneštų pokyčių i teatrą. Režisierius nekeitè savo darbo principo ir aktorių ruošimo sistemos. Jis teigè, kad „bet kokie politiniai tikslai gali sugadinti teatrą" (Stanislavsky 1987: 429).

Kaip teigia J. Kalašnikovas, Stanislavskis aktorių laikè „,svarbiausiu teatro elementu, ne atlikejju, o kūrèju“ (Kalašnikovas 1957: 6). Repetuodamas jis mègino vienodai ugdyti aktorius siekdamas lygiavertiškai išugdyti ir fizinę, psichologinę aktoriu galią. Stanislavskis siekè, kad aktoriaus meistriškumas būtų išugdomas ir neatsiejamas nuo meno kūrinio idejjos ir uždavinio. Kalašnikovas vienu svarbiausiu sistemos aspektu laiko sieki natūraliai pažadinti igimtas savybes ir talentus, pasąmoninę kūrybą. Todèl jis pavadina Stanislavskio sistemą „išgyvenimo sistema". Stanislavskio sistema rèmèsi aktoriaus, kaip asmens, patirtų ir išgyventų pojūčių perkèlimu ì sceną reikiamu metu, taip užtikrinant natūralią elgseną scenoje, spontaniškumą gyvybiškumą ir originalumą. Daug dėmesio aktoriai privalejjo skirti jausmų ir psichologijos analizei, taip pat sistemingai atlikti ir kartoti fizinius pratimus, teoriškai ruoštis kurti vaidmenis. Svarbu suvokti, kad Stanislavskis ir jo sistema liko nuošaliau, nes ji rèmèsi psichologija, dvasine patirtimi, pasąmone ir išgyvenimu, o ne racionaliu politiniu, aiškiai apibrèžiamu ir konkrečiu mąstymu.

Stalinas suvokè teatro daromą ittaką publikai, todèl valstybė labai daug investavo ir drauge kontroliavo socrealizmo diegimą teatre. Abejonèms dèl naujos estetikos teatre suvaldyti buvo pasitelktas Stanislavskis. Jo pirmieji nuosaikaus realizmo darbai, jo užsitarnauta pagarba visuomenèje ir amžius leido Stanislavski paversti Stalino prototipu teatre, tad labai greitai buvo pradètas formuoti Stanislavskio kūrybos ir asmens garbinimo kultas, o MCHAT teatro estetika laikyta nepralenkiama (Balevičiūtè 2007: 47). Žinoma, greta Stanislavskio buvo ir kitų kūrèjų, kurie dabar vertinami dèl savo inovatyvių sistemų ir estetikos, tačiau daugelis jų neitiko valdžiai ar tiesiog nebuvo priimtini masėms. Iki Stanislavskio mirties MCHAT teatras tapo pavyzdiniu teatru visoje SSRS, o jo metodologija privaloma visoms aukštosioms teatrinems mokykloms (Benedeti 1990: 346). 
Visi Stanislavskio vykdyti eksperimentai ir politines viršūnes netenkinančios mintys buvo tiesiog nutylimos, o viskas, kas buvo sietina su dvasingumu ir psichologija, buvo laikoma pernelyg abstraktu, individualistiška, smulkmeniška, jeigu tai palygintume su didžiosiomis socializmo statybomis, todèl nesiderino su nauja valstybès politika ir tokie aspektai buvo tiesiog atmesti. Politinė ideologija atmetè visas psichologijos mokyklas pasilikdama tik biheviorizma, todèl socialistinio realizmo vaidybos teorijos pagrindu tapo tik fizinè (konkreti) Stanislavskio metodo dalis. Jeanas Benedetti teigia, kad CK siekè ir vertè sukonkretinti ši metodą iki visiško realistinio modelio atsisakant dvasios ir pasąmonès terminų. Dèl istorinių aplinkybių ir stalinistinès tvarkos visuomenèje susiformavo metodas, kuri teatrologai ivardina kaip fizinių veiksmų metoda, kildinamą iš Stanislavskio sistemos.

Svarbu atkreipti dèmesi, kad naujoji socrealistinè vaidybos sistema buvo grindžiama Stanislavskio tekstais ir praktikomis, tačiau savos, naujos rašytinès formos neturejo, bent jau oficialios. Socrealistinè vaidybos sistema egzistavo kaip reikalavimas pedagogams ruošiant naujus aktorius, o juos ruošti reikejjo vadovaujantis socrealizmo gairèmis, kurios, skirtos visam SSRS menui kontroliuoti ir suvienyti, buvo suformuotos $1934 \mathrm{~m}$. Tada rašytojų sąunga suvažiavime išskiria pagrindinius socrealizmo igyvendinimo meno kūrinyje principus (Juraga 2002: 68). Buvo suformuotos gairès, kurios nurodè, kad meno kūrinys turi būti atpažǐstamas, suprantamas, kasdienis, atspindintis dabarti ir politinę ideologiją.

Remiantis Stanislavskio mokymais ir atsižvelgiant į naujus reikalavimus, naujoji vaidybos sistema formavosi praktikoje. Žinoma, svarų indèli i i sistemos bruožų formavimąsi įnešè socrealistinè dramaturgija. Nors negalima teigti, kad buvo atsisakyta psichologizmo kaip sistemos bruožo, bet oficialiuoju lygmeniu tai buvo kritikuojama ir atmesta kaip per daug abstraktūs ir nekonkretūs bruožai, kurių naujas, socialistinis žmogus gali nesuprasti. Naujoji vaidybos teorija iš esmès buvo papildyta svarbiausiu nauju uždaviniu - diegti ir stiprinti socrealistinio meno gaires vaidyboje. Atsirado taisyklè, kuri nurodè, kad aktorius turi vaizduoti sveika, laiminga, stipru, sovietinę ideją palaikantị ir ja besidžiaugiantị personaža, kuris nori kitus ikvėpti, o netikinčius ja - ittikinti (Dapšytė 2014: 51). Iš esmès socrealistinès vaidybos teoriją galima būtų pavadinti tokia, kuri privalejo retransliuoti partijos pasiūlytas vertybes ir realybès vizijas iš teatro scenos pasitelkiant aktorius.

\section{SOCREALISTINĖ IDEOLOGIJA LIETUVOS SCENOSE}

Siekiant pailiustruoti ryškiausius Stanislavskio ir socialistinio realizmo kombinuotus raiškos principus, kurie atsiskleidè Lietuvos teatro scenoje, paranku aptarti politinio lyderio, liaudies priešo, herojaus vaidmenis. Toks vaidmenų kla- sifikavimas susiformavo dèl politinių ideologijos normų ir meną kontroliuojančių įstaigų kontrolès, nes bet kokia socialinè blogybè ar skurdas privalejo būti pašalintas iš kūrinio, o personažai, kurie negalèjo būti tik geri arba tik blogi, taip 
pat negalëjo būti vaizduojami, kad nesukeltų abejonių publikai (Frankel 1972: 125). Tai rodè, kad ideologija yra paprasta: viskas arba gerai, arba blogai (Overy 2004: 354). O tai buvo bandoma apibrèžti per CK pasiūlytas vertybes, dar „Leninas siekè per meną sukurti naujaji Sovietini žmogü", kurio vertybès ir buvo politikos padiktuotos vertybès, privalomai taikomos visiems (Overy 2004: 354). Politinis siekis, kad visas sajungos menas kurtų CK utopinę realybę, sudarè sąlygas isitvirtinti šabloniškam vaidmenų klasifikavimui (Siegelbaum 2004: 220). Valdžiai siekiant kuo greičiau užtikrinti, kad naujos taisyklès ir reikalavimai izsitvirtintu visoje SSRS teritorijoje, Lietuvoje pirmieji ryškesni socrealizmo estetikos darbai teatro scenoje atsirado iš karto po karo.

Pirmą kartą sistemos lyderio Lenino vaidmuo sukurtas 1947 m., Nikolojaus Pagodino spektaklyje „Kremliaus kurantai“", kuri režisavo Borisas Dauguvietis. Tiriant šio pastatymo recenzijas ir atsižvelgiant $i$ tuometinių teatro kritikų ižvalgas, galima daryti prielaida, kad spektaklis buvo "teisingas", nes visas recenzijas lydi leitmotyvas, nurodantis, jog svarbiausiu spektaklio aspektu yra laikoma ideologija, o ne estetinè teatro kalba. Kaip teigia B. Šileika, Dauguvietis „teisingai suprato pjesės idèjinę liniją“, o spektaklis pavykęs dèl „,komunistinių idejjų îsisavinimo“" (Dapšytė 2014: 60). A. Guobys teigia: „Šis pastatymas savotiškai paspartino ne tik socialistinio realizmo metodo izsisavinimo problema, o ir padejo visam teatro kolektyvui apčiuopti vieningą kūrybinę kryptį“ (Guobys 1970: 10). Plakatiškumo, šabloniškumo bruožų atsiskleidimą Juozo Sipario kurtame Lenino vaidmenyje galime atpažinti iš B. Šileikos minimų pastabų: „Kai pamatome Leniną savo darbo kabinete, mums atrodo, kad toms scenoms aktorius labiausiai atsidejęs ir ruošèsi, ị tuos paveikslus aktoriaus dèmesys ir buvo nukreiptas" (Šileika 1947: 8), Taip pat kita citata: , „<...> J. Siparis parodo daug vaizduojamojo charakterio didybès žybtelèjimu“" (Šileika 1947: 8). Analizuojant tokias recenzijų mintis ir turint keletą spektaklio nuotrauku, galime susidaryti ivaizdi, kad socialistinei vaidybai buvo būdingas plakatiškumas - aiškūs atpažistami gestai, mizanscenos, temos, kurios naudojamos sovietiniuose plakatuose, reklamose, piešiniuose. Lenino tiek daileje, tiek teatre buvo vaizduojamas laikantis panašių konvencijų. Ideologijos vado kūno kalba buvo apipinta simboliais - ištiestas Lenino pirštas i prieki - tai nuoroda į šviesesni rytojų. M. Petuchauskas „Kremliaus kurantus“ pavadina vienu pirmujuc politinio teatro pavyzdžių lietuvių scenoje. Tai svarbus tuometinis liudijimas, kad lietuvių teatras formuojamas „teisingai". Lenino ir kitú politiniu lyderių vaizdavimas įrodo, kad ideologija ir politkorektiškumas buvo svarbiausi aspektai, o šis atvejis atskleidžia, kad vaidybos sistema buvo prieštaringa, nenusistovejusi - tarsi psichologija ir neatmetama, tačiau bandoma remtis štampais, plakatiškai atmetant Stanislavskio plètotą autentiškumą.

Siekiant įtvirtinti naują politinę santvarką lygiai taip pat, kaip buvo svarbu vaizduoti jos idealus ir jų vertybes, buvo svarbu vaizduoti tuos, kurie priešinosi naujajai santvarkai. Sistemos priešo vaidmeniui nagrinèti išskirsiu Juozo Baltušio spektaklyje "Gieda gaideliai“" sukurtą Rūkienès vaidmenị. Rūkienè recenzijose ivvardinama kaip buožè: „Svarbiausias pjesės vertingumas ir įdomumas yra ittikinantis žvėriško Lietuvos buožijos veido 
pavaizdavimas, jos gilaus priešiškumo darbo valstiečiu masèms, kurios buvo žiauriai eksploatuojamos ir skurdinamos, parodymas" (Kutorgiené 1948: 9). Pjesė baigiasi naktimi, kurios pabaigą akcentuoja visus keliantis i naują santvarką gaidžio giedojimas (Dapšytė 2014: 63). Šitaip dramaturgijoje paniekinamos tarpukariu Lietuvoje susiformavusios gyvenimo sąlygųos ir išaukštinamas komunistinis - geresnio gyvenimo modelis. Šioje pjesëje vyksta klasių kova. Kaip teigè Jonas Lankutis, ši pjesė turëjo parodyti publikai ir „liudyti apie išnaudotojų žiaurumą laikyti ivvykių fone žmogiškosios sąžinès veidrodį“ (Lankutis 1983: 51).

1948 me. Vilniaus valstybiniame dramos teatre Aleksandras Kernagis pastate spektaklì "Gieda gaideliai“. Reikšmingą pastabą apie Rūkienès vaidmeni pateikia T. Černiauskas: „>...> stengèsi daugiau pavaizduoti Marytès asmeninę dramą: sutryptą meilę, nusivylimą vyru, skausmą dèl nuolatinio ujimo iš Rūkienès pusès, negu pasipiktinimą Rūkų ir Puronų niekšybėmis, negu protestą prieš žmogaus paniekinimą" (Lankutis 1983:51). V. Ruminas teigia: „didžioji byla tarp darbo valstiečiuc ir buožių bus laimèta ir kad ją laimèsią darbo valstiečiai“" (Rudminas 1948: 7). Tikètina, kad senojo lietuvių kaimo vaidmenys turejo būti kuriami socialinių, aiškių, plakatiškų, archetipiškų personažų pagrindu, o ne kaip individualiai savarankiški, psichologiškai motyvuoti veikèjai. Rūkienès vaidmuo šabloniškai apipinamas klišèmis - tamsia, skurdžia apranga - godumui pašiepti, veidas grimu paverčiamas kuo rūstesnis. Puikiai pasitarnauja sistemos priešo idèjai stiprinti ne tik psichologinis, bet ir fizinis, prieš vaikus naudojamas smurtas. Tačiau iš turimų duomenų galime dary- ti prielaidą kad Rūkienè ir jos šeima pasiturintys Lietuvos tarpukario valstiečiai - vaizduojami plakatiškai ir gana šabloniškai kaip kitus engiantys žmonès - visuomenès parazitai. Sistemos priešo vaidmenį labiau apibrèžia dramaturgija. Šiame pavyzdyje galima iž̌velgti Stanislavskio sistemos pamynima, kadangi visas spektaklis apipinamas iliustratyviais elementais, kurie yra nusistovèjusios klišès ir šablonai. Čia vèl svarbiau yra politinè-ideologinè linija ir istorijos revizionizmas, bandoma paniekinti istorini Lietuvos kaimą ir pasiturinčiuosius iškeliant darbo, eilinị žmogų.

Sistemos herojus buvo suprantamas kaip nuolankiai atsiduodantis naujai pasaulio tvarkos vizijai, besiaukojantis dèl valstybès ir partijos tikslų. Pirmieji pokario metai buvo ypač svarbūs sovietams, kurie tuo metu naudojosi herojaus paveikslu scenoje kaip įrankiu, kuris gali įtikinamai ir plačiai skleisti patriotines idèjas, ypač skatinamąsias, socialistines revoliucines (Dementavičiūtè: 2019: 38). Kadangi teatras vadovavosi MCHAT gairèmis, spektakliuose dominavo karo ir liaudies heroizmo tematika (Dementavičiūtè: 2019: 38).

Sistemos herojaus vaidmuo aptartame kontekste atsiskleidžia R. Juknevičiaus režisuotame spektaklyje "Šarvuotis 14 69", pastatytame $1941 \mathrm{~m}$. Vilniaus valstybiniame dramos teatre. Vsevolodo Ivanovo pjesèje veiksmas vyksta Sibire, o dèmesio centre raudongvardiečių ir baltagvardiečių kova. Pjesejje yra daug kautynių scenų, akcentuojamas liaudies išlaisvinimas ir jos naujas santykis su išvaduotojų vedliais. Recenzentai, nagrinèdami spektaklį, daugiausiai dèmesio skyrè būtent masinių kautynių scenų aptarimui (Petuchauskas 1979: 30). M. Pe- 
tuchauskas recenzijoje ši spektakli pavadina pavykusiu režisieriaus siekiu sukurti revoliucijos įspūdi scenoje: „R. Juknevičius atskleidè kiekvieno liaudies scenos dalyvio charakteri ir kartu pateikẻ bendrą ispūdingą minios piešini išryškindamas jos siekius ir svajones" (Petuchauskas 1979: 30).

Svarbu paminèti ir oficialiai pripažinto socrealistinio rašytojo J. Baltušio kritika, išreikštą dèl pačios dramaturgijos kokybès, klausiančią, ar kūrini iš viso galima laikyti pjese (Baltušis 1941: 9). Rašytojas, pažymėdamas nuosaikią poziciją partijos atžvilgiu, išryškina Lenino vardo galią suburti. Užsimenama tik tiek, kad „Drg. Derkintis privertè visiškai įtikèti jo kiniečiui - proletarui, didvyriškai paaukojusiam savo gyvybę už darbo žmonių pergalę" (Baltušis 1941: 9).

Kitas svarbus šio spektaklio aspektas yra pats herojus ir jo tapatybè. Šiame spektaklyje naujosios visuomenès herojumi tampa kinas Sin Bin U (Valerijonas Derkintis). Naujas herojus šiame spektaklyje skelbia žinia, kad Sovietų Sajungoje daugybė skirtingų tautų siekia vieno tikslo, atmesdamos savo individualius ar savos tautos tikslus, ir kovoja už socialistinę santvarką.

Esminis sistemos herojaus vaidmens tikslas išlieka politinis angažuotumas ir patriotizmo skatinimas. Spektaklyje aktorių darbas orientavosi labiau į mizanscenų atlikimą ir jų išpildymą. Svarbu paminèti ir plakatiškuma, kuri mini recenzentai. Tai daugeli porevoliucinių spektaklių lydinti pastaba, kuri leidžia daryti prielaida, kad visas menas, staiga suvaržytas naujos meno krypties taisyklių, supanašejo ir estetinė raiška susipynè. Herojaus plakatiškumas gali būti palygintas su sovietiniuose plakatuose pieštais visuomenès herojais.

\section{IŠVADOS}

Vaidybos praktikoje ir recenzentų lakoniškose pastabose apie vaidybą galima atsekti neatitikimų vaidybos sistemai, kuri turejjo atitikti socialistinio realizmo bruožus. Labiausiai išryškèję socrealistinès vaidybos bruožai - plakatiškumas, šabloniškumas, konvencinis heroju, priešų vaizdavimas. Neatitikimas tikrųu Stanislavskio minčių, kuris siekė aktorių išvaduoti nuo pasikartojimo, klišių ir šablonų, kilo dèl politinių reikalavimų, vykdytos kontrolès ir persekiojimų. Teigti, kad psichologinès vaidybos pėdsakų aptikti neimanoma, negalima, bet tai neaptariama nei recenzentuc atsiliepimuose, nei aktorių duotuose interviu, memuaruose. Recenzentai labiau gilinosi i poli- tinę ideologiją ir socrealizmo gairių atitikimą. Stanislavskio sistema buvo paranki tuo, kad ji egzistavo rašytine forma ir buvo jau issitvirtinusi teatro pasaulyje, todèl socrealizmas, kuris mégino būti artimas realizmui, tiesiog pasinaudojo esama medžiaga. Socialistinio realizmo vaidybos teorija, kurią galima kildinti iš fizinių Stanislavskio principu, kito ir plètojosi per visą savo egzistavimo laikotarpi, o psichologiniai, dvasiniai ir išgyvenimų principai buvo eliminuoti tik iš oficialiojo sistemos lygmens. Tad galima kelti prielaida, kad socrealistinès vaidybos teorija yra Stanislavskio sistema, apipinta ideologiniais, propagandos ir politinès ideologijos skleidimo uždaviniais. 


\section{Literatūra}

Adomaitytė Aldona. 2004. Lietuvos vaidybos mokykla. Teatro edukologija. Vilnius: Lietuvos muzikos ir teatro akademija.

Balevičiūtè Ramunè. 2007. Lietuviu aktorinés mokyklos formavimosi savitumai. Vilnius: Lietuvos muzikos ir teatro akademija.

Balevičiūtè Ramunè. 2007. Menotyra. Dar vienas žvilgsnis i psichologini realizma ir jo ispaudus lietuviu teatre. Vilnius: Lietuvos mokslu akademijos leidykla.

Baliutytė Elena. 2002. Laiko ikaitè ir partneré: lietuviu literatūros kritika. Vilnius: Lietuvių literatūros ir tautosakos institutas.

Baltušis Jonas. 1941. Ilgai laukta premjera Vilniaus Valstybiniame Teatre. V. Ivanovo „Šarvuotis 1469“, Tiesa 4: 9.

Benedeti Jeane. 1990. Stanislavski: A biography. New York: Routledge.

Dapšytė Goda. 2014. Sovietinès cenzūros poveikis Lietuvos teatro diskurso raidai. Daktaro disertacija. Vilnius: LMTA.

Dementavičiūtè-Stankuvienè Deimantè. 2019. Nacionalinio herojaus reprezentacijos kaita sovietiniame ir postsovietiniame Lietuvos dramos teatre. Daktaro disertacija. Kaunas: Vytauto didžiojo universitetas.

Efimova Alla. 1997. To touch on the raw: the aesthetic affection of social realism, Art Journal 56.

Ellis Andrew. 2012. Socialist Realisms: Soviet Painting 1920-1970. Milano: Skira Editore.

Frankel Tobia. 1972. The Russian Artist. New York: Macmillan Company.

Giesz Ludwig. 1994. Phänomenologie des Kitsches. Frankfurt am Main: Fischer Taschenbuch Verlag.

Guobys Aleksandras. 1970. Lenino paveikslas Lietuviu teatre. Vilnius: Lietuvos TSRS teatro draugija.

\section{Nuorodos}

${ }^{1}$ Dèl šių teiginių M. Gorkis buvo sulaukęs kritikos dar ir iš V. Lenino, kai parašè „Motiną". V. Leni-
Juraga Dubravka. 2002. Socialistic cultures East and West. Connecticut: Praeger.

Kalašnikovas J. 1957. K. Stanislavskio pokalbiai Didžiojo teatro studijoje 1918-1922 metais. Vilnius: Lietuvos TSR teatro draugija.

Klivis, Edgaras. 2004. Metaforinio teatro poetika. 8-9 dešimtmečiu Lietuvos teatro režisūra: tekstai ir kontekstai. Daktaro disertacija. Kaunas: Vytauto Didžiojo universitetas.

Kutorgienė Zita. 1948. Smetoninis kaimas scenoje, Tarybu Lietuva 3: 14.

Lankutis Jonas. 1983. Lietuviu tarybine dramaturgija. Vilnius: Vaga.

Marowitz, Charles. 2006. Stanislavskis prieš Čechova, Kultūros barai 11: 32-35.

Nelson Cary, Lawrence, Grossberg. 1988. Marxism and the Interpretation of Culture. University of Illinois Press.

Overy Richard. 2004. The Dictators: Hitler's Germany, Stalin's Russia. University of Exeter: W. W. Norton \& Company.

Petuchauskas Markas. 1979. Pirmasis tarybinio teatro sezonas. Lietuviu tarybinis teatras: 1940-1956. Vilnius.

Rudminas Vytautas. 1948. Didžioji byla. J. Baltušio "Gieda gaideliai“ Lietuvos TSR valstybiniame dramos teatre, Tiesa 9: 29.

Siegelbaum Lewis, Sokolov Andrei. 2004. Stalinism as A Way Of Life. Yale University Press.

Stanislavsky Konstantin. 1987. Mein Leben in der Kunst. Berlin: Das Europäische Buch.

Stanislavskis Konstantinas. 1947. Aktoriaus saviruoša. Kaunas.

Šileika Bronius. 1947. „Kremliaus kurantai“ Lietuvių scenoje, Tiesa 11: 27.

nas ǰžvelgè, kad terminas religija gali būti ne taip suprastas, nes sovietinis žmogus yra ateistas. 